\title{
EFFECT OF IRRIGATION REGIMES ON THE QUALITY, GROWTH, AND PRODUCTIVITY OF MANGO
}

Waleed Mohammed Bassiuony Darwisch* and Sayed El-soufany** ABSTRCT

The situation of water shortage in arid and semiarid regions is getting worse due to the unexpected climatic changes, continuous population growth and increasing consumption of fresh water in the agricultural sector. The aim of study was to evaluate the impact of irrigation regimes on quality, tree growth, and mango yield, under semi-arid climate. Therefore, these experiments for mango trees (Eiwas) were carried out during 2013 and 2014 in soil of sandy soil under different irrigation regimes. The drip irrigation system was used. The mango tress was exposed to four water regimes through two years $(T 1=100 \%$ of available water as a control, $T 2=85 \%$ of T1, T3 $=75 \%$ of $T 1$ and $T 4=60 \%$ of field T1). Manure was added to all treatments with the same percentage, while compost in addition to manure was added the last three of them. The results showed that, the $T 2$ treatment proved to be the most appropriate, since it allowed the trees to reach the highest yield (6360.9 $\mathrm{Kg} / \mathrm{fed})$ and the best water-use efficiency $\left(1.13 \mathrm{~kg} / \mathrm{m}^{3}\right)$. When, the T4 proved to be the lowest values, since it allowed the trees to reach the lowest yield $(2166.6 \mathrm{Kg} / \mathrm{fed})$ and the lowest water-use efficiency $(0.55$ $\left.\mathrm{kg} / \mathrm{m}^{3}\right)$. There were good relationships between water requirements with yield, volume, total acidity and leaf area under four water regimes $\left(R^{2}\right.$ equal to 0.72, 0.81, 0.86 and 0.99), respectively. As well as there were good relationships between water use efficiency with yield, volume, total acidity $\left(R^{2}\right.$ equal to $\left.0.92,0.53,0.81\right)$, respectively. It can be concluded that, T2 with farmyard manure and compost was the most appropriate amount of water under the climatic conditions of the study area was, because that achieved high values of growth, productivity and quality of mango.

\footnotetext{
*Assistant Prof. of Agric. Eng. Evaluation of Natural Resources Department, Environmental Studies and Research Institute, Sadat City University

** Post graduate at Evaluation of Natural Resources Department, Environmental Studies and Research Institute, Sadat City University
} 
Although the study was conducted through two years conclusive suggestions about the effect of the various irrigation treatments on vegetative and fruit growth and quality can only be made after a longer time period because of seasonal differences in climate and the alternating growth habit of mangoes.

Keywords: Irrigation regimes - Water use efficiency - Drip irrigationMango growth

\section{INTRODUCTION}

hortage of water represents one of the most limiting factors in crop production worldwide. This necessitates rationalizing water use in crop production. Strategies to increase efficiency of water use in agriculture are based on two approaches: the technological and biological methodologies. Technological methods include utilization of advanced irrigation systems and scheduling of irrigation frequencies. Biological approach includes using potentially drought resistant plant species and breeding drought tolerant crop plants (Mohamed, 2000). For that we applied this study to test the effect of irrigation water regimes on growth, yield and quality of mango.

Mango (mangifera indica L.) is a very popular fruit in many countries especially Egypt. It is truly called the 'King of fruits, it is a very high fruit consumption because it is delight all senses (FAO Production Yearbook, 2007). In Egypt, mangoes grow well mostly in loamy or sandy well-drained soils. Mango economically ranked third after citrus and grapes. The total area of mango in Egypt was 241.1 thousand feddan in 2013, fruitful area was 200.88 thousand feddan, while, the total production was 712.5 thousand tons (MALR, 2013). For examples, Pavel, and Villiers. (2004) studied the responses of mango trees to reduced irrigation $\quad$ regimes. Old Kent mango (Mangifera indica) trees were subjected to 5 irrigation regimes consisting of the control, a regulated deficit and 2 progressively reduced irrigations treatments as well as the farm control. Frequent applications of irrigation water led to water savings in the range of $32-58 \%$ water in the 4 treatments compared to the farm control. 
Reduced irrigation treatments significantly reduced the vegetative growth compared with the farm control. Yield was not significantly affected by the various irrigation treatments. However, differences in yield between treatments seemed to be mainly related to fruit number indicating that the reduced irrigation treatments might have affected rather growing conditions before flowering or during the early stages of fruit growth than later in the season. (Geerts and Raes 2009) reviewed the recent research on the maximization of productivity per unit of water by deficit irrigation. They concluded that, in areas where the available water supply limits agricultural production, deficit irrigation will gain importance over time as farmers strive to increase the productivity of their limited land and water resources. Farmers must choose crops and irrigation strategies carefully to maximize the value of their crop and livestock production activities, while ensuring the sustainability of agriculture. Deficit irrigation will play an important role in farm-level water management strategies, with consequent increases in the output generated per unit of water used in agriculture. For instance, water saved by deficit irrigation can be used to irrigate more land (on the same farm or in the water user's community), which given the high opportunity cost of water may largely compensate for the economic loss due to yield reduction (Ali et al., 2007). A field experiment for drip irrigation scheduling in mango based upon the pan evaporation replenishment rate in five to ten-year-old trees of Arka Anmol mango was conducted. Four levels of open pan evaporation based drip irrigation schedules $(25,50,75$ and $100 \%$ pan evaporation replenishment) and one rainfed plot to serve as control with 5 replications were maintained under randomized block design. The long term experimental results revealed that significantly maximum canopy volume, fruit number and yield were recorded due to daily drip irrigation at $75 \%$ pan evaporation replenishment. The fruit quality such as fruit dry weight, pulp weight, peel weight, stone weight and TSS were observed to be improved due to drip irrigation but remained at par with rain fed (control). Maximum fruit volume and soil moisture content was recorded due to daily drip irrigation at $100 \%$ evaporation replenishment (Dinesh et al., 2008). 
Spreer et al. (2009a) investigated the possible negative effects of deficit irrigation on yield and fruit growth, 196 ten-year-old "Chok Anan" mango trees, at an experimental plot near Chiang Mai, Northern Thailand, were assigned to five irrigation regimes commencing two weeks after onset of flowering: a) full irrigation (FI) as calculated based on the climatic water balance according to the Penman-Monteith equation; b) deficit irrigation (DI) with $75 \%$ of FI (DI75); c) deficit irrigation with $50 \%$ of FI (DI50); d) partial root zone drying (PRD) with $50 \%$ of FI; and e) no irrigation. After two years of experiment the results showed a potential to increase water-use efficiency (WUE) of mango by deficit irrigation. Only in one-year yield in PRD-irrigated trees was significantly lower than in FI trees. Especially in the second year there was no significant difference between DI50 and PRD. DI75 had the greatest yield, however not significantly higher than FI. Differences in yield were mainly attributed to the number of fruits per tree and no obvious influence of the irrigation regime on fruit growth could be monitored. Spreer et al. (2009b) assessed the response of mango trees to varying amounts of available water. Yield response and fruit size distribution were measured and WUE was determined for partial root zone drying (PRD), regulated deficit irrigation (RDI) and irrigated control trees. Four irrigation treatments have been evaluated with respect to mango yield and fruit quality: (a) control ( $\mathrm{CO}=100 \%$ of ET c), (b) (RDI $=50 \%$ of ETc), (c) (PRD $=50 \%$ of ETc, applied to alternating sides of the root system) and (d) no irrigation (NI). It was concluded that deficit irrigation strategies can save considerable amounts of water without affecting the yield to a large extend, possibly increasing the average fruit weight, apparently without negative long term effects. (Silva et al., 2009) studied the wateruse efficiency and evapotranspiration of mango orchard grown in northeastern region of Brazil. The experimental plot was irrigated with a sprinkler irrigation system based on four irrigation levels $(\mathrm{T} 1=70 \%$, T2 $=80 \%, \mathrm{~T} 3=90 \%$ and $\mathrm{T} 4=100 \%$ of ETo. Results showed that ET and WUE are strongly influenced by soil water availability. Mango yield varied from a minimum value of 28.06 ton/ha in treatment $\mathrm{T} 4$ to a 
maximum value of 31.06 ton/ha in treatment T3. Such difference was found to be statistically significant $(\mathrm{P}<0.05)$ by Tukey's test. Results also indicated that WUE values based on irrigation and evapotranspiration were maximum and minimum for low (treatment T1) and high (treatment T4) water levels, respectively. Durán Zuazo et al. (2011) investigated the impact of sustained-deficit irrigation (SDI) strategies on fruit yield and quality, tree growth, and mineral status under a Mediterranean subtropical climate. Three sustained-deficit irrigation treatments were applied to mango trees: SDI-1 (33\% ETc), SDI-2 (50\% ETc) and SDI-3 (75\% ETc). The stress treatments were compared with a control (C-100) irrigated at $100 \%$ ETC. The response of fruit yield, number of fruits, fruit size and quality, and macro- and micronutrients in leaves was determined. Results indicated that, the SDI-2 treatment proved to be the most appropriate SDI treatment, since it allowed the trees to reach the highest yield $\left(18.4 \mathrm{t} \cdot \mathrm{ha}^{-1}\right)$ and the best water-use efficiency $\left(7.14 \mathrm{~kg} \cdot \mathrm{m}^{-3}\right)$. However, fruit size was higher for trees of the SDI-3 and C-100 treatments, since they reached significantly higher length and width. In conclusion the SDI treatment providing $50 \%$ of ETC is recommended for mango orchards in order to attain the highest yields and the best water-use efficiency under a Mediterranean subtropical climate. Therefore, the objective of this study was to assess the effect of mango trees to deficit irrigation strategies in terms of fruit yield, quality, and tree growth. Also, to estimate the effect of water deficit on water use efficiency.

\section{MATERIALS AND METHODS}

\section{Experimental site and climate}

Field experiments were conducted during the 2013 and 2014 seasons at EL Sofany farm, Wadi El-Natrun City, El-Beheira Governorate, Egypt. The location sited at a longitude of $30.23^{\circ} \mathrm{E}$, Latitude $30.22^{\circ} \mathrm{N}$. $(28 \mathrm{~m}$ Below sea level). Chemical properties and mechanical analysis of soil and irrigation water presented in Tables $(1,2$, and 3). Soil texture of the experimental site was sandy soil with water field capacity of $19.22 \%$, welting point of $10.06 \%$, and bulk density of $1.45 \mathrm{gm} / \mathrm{cm}^{3}$. 
Table (1): Soil chemical properties of the studied area.

\begin{tabular}{|c|c|c|c|c|c|c|c|c|c|c|c|}
\hline \multirow[t]{2}{*}{ Depth } & \multirow{2}{*}{$\begin{array}{c}\text { EC } \\
\text { (ds. m-1) }\end{array}$} & \multirow[t]{2}{*}{$\mathrm{pH}$} & \multicolumn{4}{|c|}{$\begin{array}{c}\text { Cations } \\
\text { (meq.L-1) }\end{array}$} & \multicolumn{4}{|c|}{$\begin{array}{c}\text { Anions } \\
\text { (meq.L-1) }\end{array}$} & \multirow[t]{2}{*}{ SAR } \\
\hline & & & $\mathbf{C a} 2+$ & $\mathrm{Mg}_{2+}$ & $\mathrm{Na}+$ & $\mathbf{K}_{+}$ & $\mathrm{Co}_{3}{ }^{-1}$ & $\mathrm{H} \mathrm{Co3}^{1}$ & $\mathrm{Cl}^{1}$ & $\mathrm{SO}_{4}^{-2}$ & \\
\hline $30-60 \mathrm{~cm}$ & 1.07 & 8.20 & 26 & 15 & 54.4 & 2.1 & --- & 6 & 52 & 39.5 & 8.43 \\
\hline
\end{tabular}

Table (2): Soil mechanical analysis class of the studied area

\begin{tabular}{|l|l|c|c|c|l|l|}
\hline \multirow{2}{*}{ Depth } & \multicolumn{6}{|c|}{ Mechanical analysis class } \\
\cline { 2 - 6 } & Coarse & \multicolumn{2}{|c|}{ Particle size distribution } & $*$ SP\% & Texture \\
\hline $30-60 \mathrm{~cm}$ & $\begin{array}{l}\text { Gravel } \\
\%\end{array}$ & Sand \% & Silt \% & Clay \% & 23 & Sand \\
\cline { 2 - 5 } & 10.5 & 93 & 1 & 6 & & \\
\hline
\end{tabular}

*SP\% is Saturation percentage (\%)

Table (3): Chemical properties and analysis of water used in irrigation

\begin{tabular}{|c|c|c|c|c|c|c|c|c|c|c|}
\hline \multirow{2}{*}{$\begin{array}{c}\text { EC } \\
(\text { ds. } \mathbf{m}-1)\end{array}$} & \multirow[t]{2}{*}{$\mathrm{pH}$} & \multicolumn{4}{|c|}{$\begin{array}{c}\text { Cations } \\
\text { (meq.L-1) }\end{array}$} & \multicolumn{4}{|c|}{$\begin{array}{c}\text { Anions } \\
\text { (meq.L-1) }\end{array}$} & \multirow[t]{2}{*}{ SAR } \\
\hline & & $\mathbf{C a} 2+$ & $\mathbf{M g}_{2+}$ & $\mathbf{N a}+$ & $\mathbf{K}+$ & $\mathrm{Co}_{3}{ }^{-}$ & $\mathrm{HCO}^{-}$ & $\mathbf{C l}^{1}$ & $\mathrm{SO}_{4}^{-2}$ & \\
\hline 0.85 & 8.22 & 1.54 & 2.31 & 3.6 & 1.02 & --- & 2.05 & 4.81 & 2.57 & 2.65 \\
\hline
\end{tabular}

\section{Experimental design and treatments}

Twenty Eiwas mango trees ( 8 years old) were selected, for receiving the experimental treatments uniform in size and vigorous in growth; four different treatments with 5 replicates. The irrigation treatments were applied (T1: $100 \%$ of the available water of soil as a control, T2: $85 \%$ of T1, T3: $75 \%$ of $\mathrm{T} 1$ and T4: $60 \%$ of T1). Drip irrigation system was constructed and tested in the experimental location before placing it on the mango trees. Two drip lines with ( 8 liter/hr) has been placed around each tree. All plants received the traditional and regular fertilization program, of which about 25 - $30 \mathrm{~kg}$ balady manure (farmyard manure) + $1 \mathrm{Kg}$ nitrogen, $1 \mathrm{Kg} \mathrm{K}_{2} \mathrm{O}, 500 \mathrm{~g}$ super phosphate $\left(15.5 \% \mathrm{P}_{2} \mathrm{O}_{5}\right) /$ plant/year added in December (winter additions). $5 \mathrm{Kg}$ Compost was added to (T2, $\mathrm{T} 3$ and T4) only.

\section{Measurements}

\section{Irrigation water requirement}

The FAO Penman-Monteith method (Allen et al., 1998) was used to calculate the reference evapotranspiration ETo in the CROPWAT 
Program. Crop water requirements (ETc) over the growing season were determined from ETo according to the following equation using crop coefficient Kc:

$$
\mathrm{ETc}=\mathrm{Kc}^{*} \mathrm{ET}_{\mathrm{o}}
$$

Where ETc is the crop water requirement, $\mathrm{Kc}$ is the crop coefficient and ETo is the reference evapotranspiration. Since there was no rainfall during the experimental period, net irrigation requirement was taken to be equal to ETc. The total amounts of irrigation water applied in the irrigation levels in this study were $6545 \mathrm{~m}^{3} / \mathrm{fed}$ in $\mathrm{T}_{1}, 5564 \mathrm{~m}^{3} / \mathrm{fed}$ in $\mathrm{T}_{2}$, $4909 \mathrm{~m}^{3} / \mathrm{fed}$ in $\mathrm{T}_{3}$ and $3974.4 \mathrm{~m}^{3} / \mathrm{fed}$ in $\mathrm{T}_{4}$. The water requirement was determined for different months based on crop growth stages and climatic data.

\section{Water use efficiencies (WUE)}

Water use efficiency $\left(\mathrm{kg} / \mathrm{m}^{3}\right)$ was calculated as the ratio between total fresh yield at harvest ( $\mathrm{kg} / \mathrm{fed})$ and total water used $\left(\mathrm{m}^{3} / \mathrm{fed}\right)$ ) ) according to the following equation by (Lovelli et al., 2007). WUE $=\mathrm{Y} / \mathrm{W}\left(\mathrm{kg} / \mathrm{m}^{3}\right)$

Where: WUE is water use efficiency $\left(\mathrm{kg} / \mathrm{m}^{3}\right), \mathrm{Y}$ is the total of mango fruit yield, ( $\mathrm{kg} / \mathrm{fed}$.) and $\mathrm{W}$ is total water applied, $\left(\mathrm{m}^{3} / \mathrm{fed}\right.$.).

\section{Physical and chemical measurement of mango Fruit:}

Fruits were harvested at maturity stage (the first week of Sept.) from each tree of various replicates and treatments. Samples of 10 randomly mature fruits from each experimental unit were used for measuring various fruit physical and chemical parameters assessed as: fruit weight (g), fruit volume $\left(\mathrm{cm}^{3}\right)$ fruit length and width $(\mathrm{cm})$ fruit diameter $(\mathrm{cm})$, shoot length $(\mathrm{cm})$, number of new shoots, leaf area $\left(\mathrm{cm}^{2}\right)$, titratable acidity $(\%)$ and total sugars percentage (SSC \%) according to A.O.A.C. (1995).

\section{Measuring soluble solids content percentage and titratable acidity}

Pulp samples were squeezed and the obtained juice was used to determine the total sugars percentage (SSC) using a hand refractometer according to AOAC (1995). The titratable acidity was determined in $5 \mathrm{~mL}$ of juice samples. For the titration, $0.1 \mathrm{~N}$ sodium hydroxide and phenolphthalein as an indicator were used according to AOAC (1995).

\section{RESULTS AND DISCUSSION}

Fig. 1 showed the average of water added $\left(\mathrm{m}^{3} / \mathrm{fed}\right)$ during the months of growth of mango trees. The maximum water added were $(774,829$, and 
$724 \mathrm{~m}^{3} / \mathrm{fed}$ ) in June, July and August months respectively, while applied water were 81 , and $74 \mathrm{~m}^{3} / \mathrm{fed}$ in January and February months respectively. This water added represented the $100 \%$ of available water (T1), when the T2, T3, and T4 for the tested rates of water deficits represented the $85 \%, 75 \%$ and $60 \%$ of $\mathrm{T} 1$ respectively. The figure also showed that, water added during the months of growth of mango trees depends only on the climatic condition (which is presented in table 4)

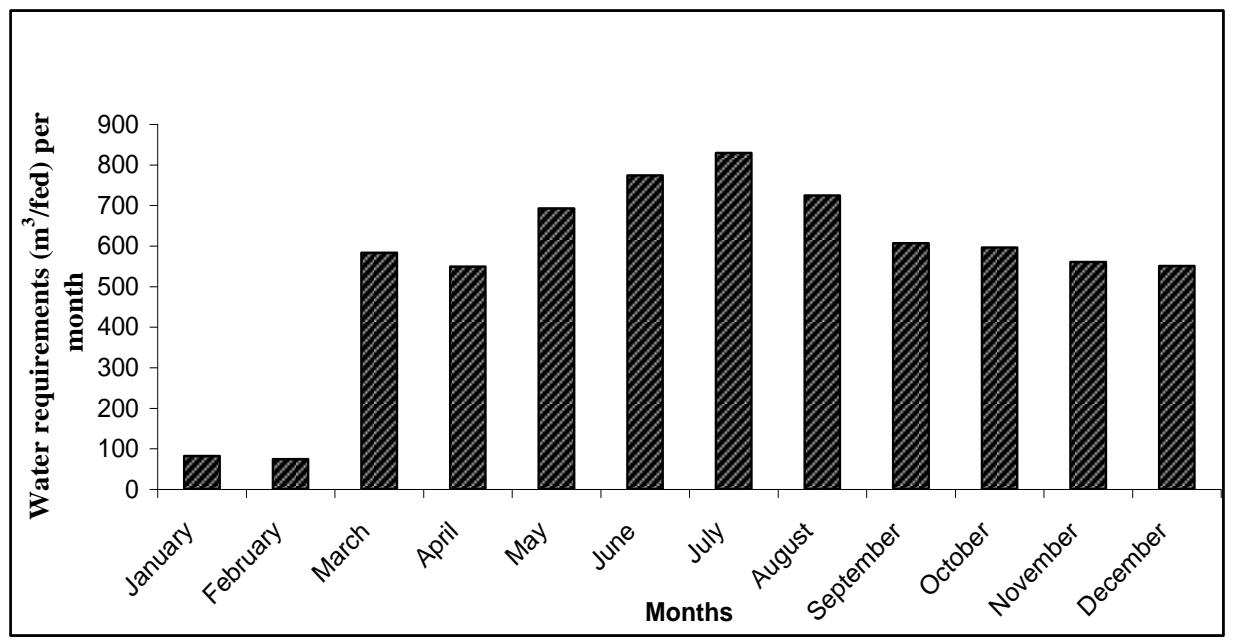

Fig.1. Average water requirements for feddan per month of two years.

Table (4): Average of temperature, relative humidity, rainfall, radiation and wind speed in two years.

\begin{tabular}{|c|c|c|c|c|c|}
\hline Month & $\begin{array}{c}\text { T-Mean } \\
(\mathbf{c})\end{array}$ & $\begin{array}{c}\text { Rainfall } \\
(\mathbf{m m})\end{array}$ & $\begin{array}{c}\text { Radiation } \\
\left(\mathbf{W a t t}^{\mathbf{2}} \mathbf{\mathbf { }}\right)\end{array}$ & $\begin{array}{c}\text { RH-min } \\
(\mathbf{\%})\end{array}$ & $\begin{array}{c}\text { W.speed } \\
\left(\mathbf{m . s}^{-\mathbf{1}}\right)\end{array}$ \\
\hline January & 12.38 & 0.18 & 3.23 & 42.23 & 0.80 \\
\hline February & 13.74 & 0.21 & 4.06 & 40.61 & 1.24 \\
\hline March & 16.28 & 0.23 & 5.20 & 30.74 & 1.67 \\
\hline April & 19.56 & 0.01 & 6.39 & 26.30 & 1.61 \\
\hline May & 23.23 & 0.08 & 6.82 & 24.45 & 1.78 \\
\hline June & 25.57 & 0.00 & 7.27 & 25.27 & 1.68 \\
\hline July & 26.41 & 0.00 & 7.23 & 33.16 & 0.51 \\
\hline August & 26.96 & 0.00 & 6.32 & 32.84 & 0.00 \\
\hline September & 25.31 & 0.00 & 5.13 & 30.93 & 0.00 \\
\hline October & 21.23 & 0.07 & 4.34 & 33.19 & 0.00 \\
\hline November & 16.87 & 0.08 & 3.23 & 41.33 & 0.00 \\
\hline December & 13.86 & 0.04 & 2.85 & 40.94 & 0.00 \\
\hline
\end{tabular}


The results in fig. 2 showed the effect of water regimes on total acidity and total sugar of mongo quality fruit. The maximum values of total acidity and total sugar were $1.3 \%$ and $22.2 \%$ found with $\mathrm{T} 1$ and $\mathrm{T} 4$ treatments, respectively. Meanwhile, the minimum value of total acidity and total sugar were $(0.78 \%$ and $15.5 \%)$ found with $\mathrm{T} 4$ and $\mathrm{T} 1$ treatments, respectively. This results means that, there was inverse relationship between applied water and total acidity, and vice versa, where there is a direct correlation between lack of applied water and total sugar of mango quality fruit. Moreover, no significant difference at 5\% between $\mathrm{T} 1$ and $\mathrm{T} 2$ for values of total acidity (\%), T3 and T4 for values of total sugar. Conversely, there were significant difference at 5\% between (T1 and T2) with (T3 and T4) in total acidity (\%). Also, there were significant difference between (T3 and T4) with (T1 and T2) in total sugar (SSC \%) of mongo quality fruit. This results agreement with Durán Zuazo et al., (2011).
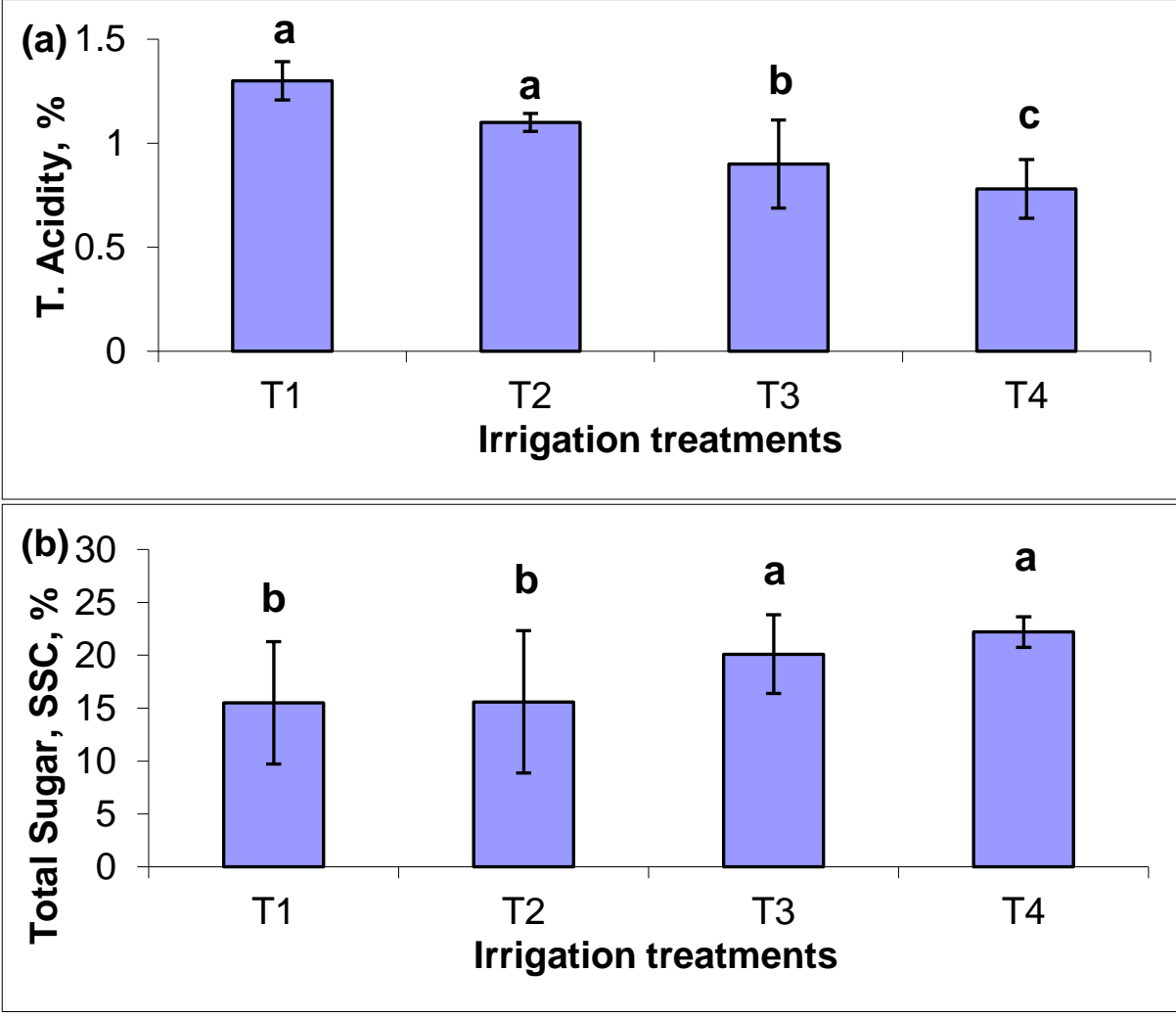

Fig. 2. The effect of water regimes on total acidity(a) and total sugar (b) of mango quality fruit. 
The results in fig. 3 indicated that, the average maximum values of leaf area $\left(\mathrm{cm}^{2}\right)$, new shoot, and shoot length $(\mathrm{cm})$ of mango fruit during the studied seasons were about $86.2 \mathrm{~cm}^{2}, 85.5$, and $20.5 \mathrm{~cm}$, respectively and found at the treatment of $\mathrm{T} 1$.

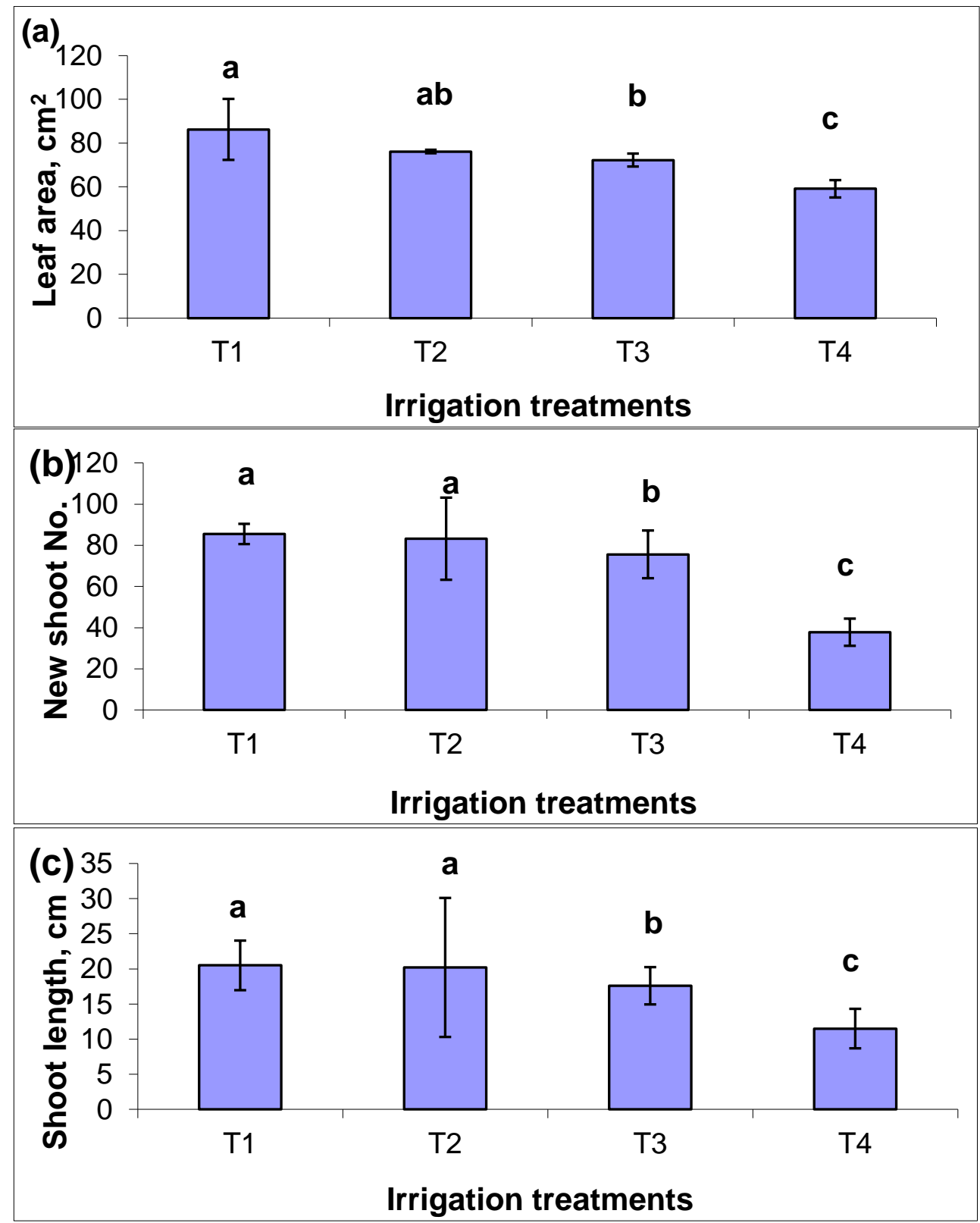

Fig. 3. The effect of water regimes on; leaf area, new shoot number and shoot length. 
While, the minimum values of leaf area $\left(\mathrm{cm}^{2}\right)$, new shoot, and shoot length $(\mathrm{cm})$ of mango fruit were about $59.1 \mathrm{~cm}^{2}, 37.8$, and $21.5 \mathrm{~cm}$ respectively found at the treatment of T4. Meanwhile, it can be noted that, no significant difference at (5\%) between $\mathrm{T} 1$ and $\mathrm{T} 2$ for values of leaf area, new shoot, and shoot length of mango fruit. Also, there was no significant difference at $(5 \%)$ between $\mathrm{T} 2$ and $\mathrm{T} 3$ for leaf area only. This results agreement with Spreer et al., (2009a)

From fig. 4, it is clear that decreasing the water applied decreased the diameter, length and volume of mango fruit. The average maximum values of dimeter, length and volume of mango fruit during the studied seasons were $\left(6.8 \mathrm{~cm}, 9.8 \mathrm{~cm}\right.$ and $\left.180.6 \mathrm{~cm}^{3}\right)$ found with T2 except only the maximum values of volume of fruit was $\left(181.1 \mathrm{~cm}^{3}\right)$ found with $\mathrm{T} 1$. Also, the minimum values of dimeter, length and volume of fruit during the studied seasons were $\left(5.9 \mathrm{~cm}, 8.5 \mathrm{~cm}\right.$ and $\left.90.6 \mathrm{~cm}^{3}\right)$ found with T4. No significant difference at $(5 \%)$ between the first and second treatments $\left(\mathrm{ET}_{1}\right.$ and $\left.\mathrm{ET}_{2}\right)$ in the values of dimeter, length and volume of fruit, and also, no significant difference at $(5 \%)$ between the third and fourth treatments $\left(\mathrm{ET}_{3}\right.$ and $\left.\mathrm{ET}_{4}\right)$ in the values of dimeter and length of mango fruit. This results agreement with Spreer et al., (2009a).

Fig. 5 shows the average values of fruit weight (gm), seed of fruit (gm), and pulp of fruit (gm) under irrigation treatments during the studied seasons. Minimum values of the fruit weight, seed of fruit, and pulp of fruit were $152.7 \mathrm{gm}, 72.8 \mathrm{gm}$, and $79.8 \mathrm{gm}$, found with T4, while the maximum fruit weight, seed of fruit, and pulp of fruit were $212.9 \mathrm{gm}$, $79.3 \mathrm{gm}$, and $133.7 \mathrm{gm}$ found with $\mathrm{ET}_{2}$. Moreover, the T2 treatment reached the highest being significant at (5\%) in comparison with the T3 treatment in (fruit weight, and pulp of fruit) and with T4 treatment in (fruit weight, seed of fruit, and pulp of fruit). Additionally, T2 treatment was not significant at (5\%) in comparison with $\mathrm{T} 1$ in (fruit weight, seed of fruit, and pulp of fruit) andT3 only in (seed of fruit). This results agreement with Spreer et al., (2009a) and Spreer et al., (2009b). 

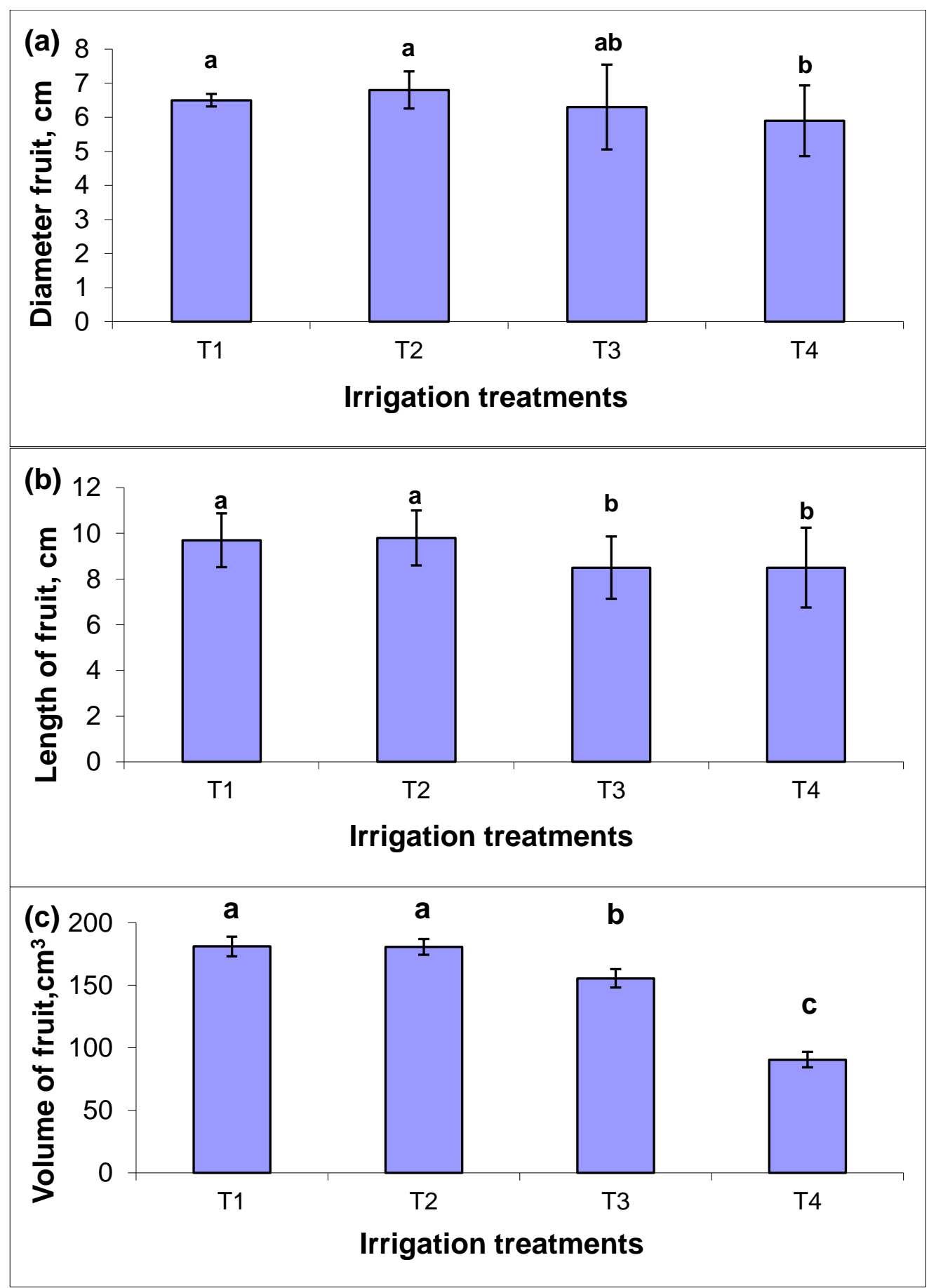

Fig. 4. The effect of water regimes on diameter, length and volume of fruit. 

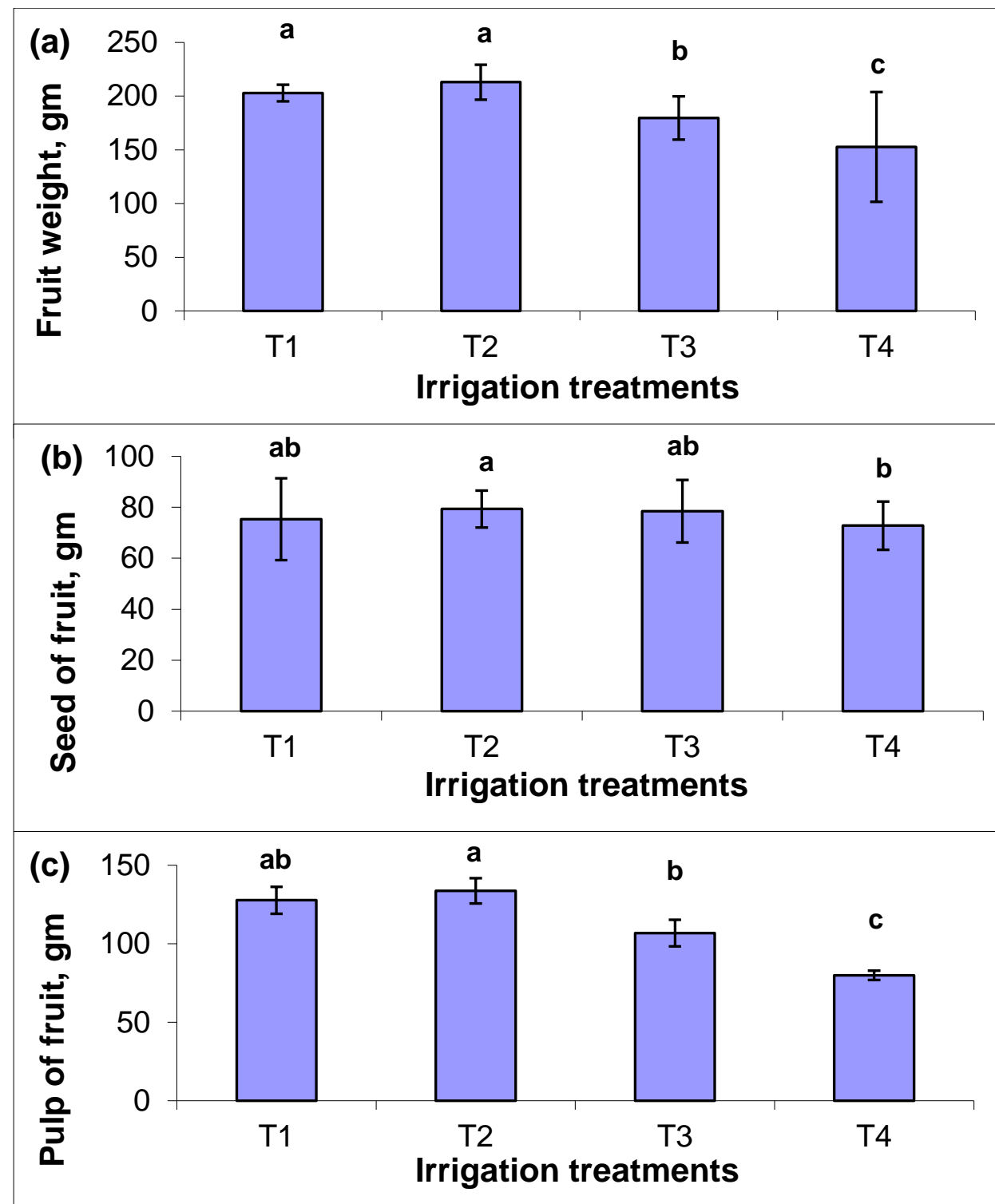

Fig. 5. The effect of water regimes on fruit weight, seed fruit weight and pulp fruit weight.

Fig. 6, represents the effect of four water regimes on (a) yield per fed., (b) yield of tree and (c) fruits number of mango through the two study years, yields were averaged; in our study area about 233 trees per fed are distributed in terraces and fruit yields were (5848.3, 6360.9, 2679.5, and $2166.6) \mathrm{kg} / \mathrm{fed},(25.1,27.3,11.5$, and 9.3$) \mathrm{kg} /$ tree and $(123.8,128.5,64$, and 61) fruits/ tree for the T1, T2, T3 and T4 treatments respectively. 

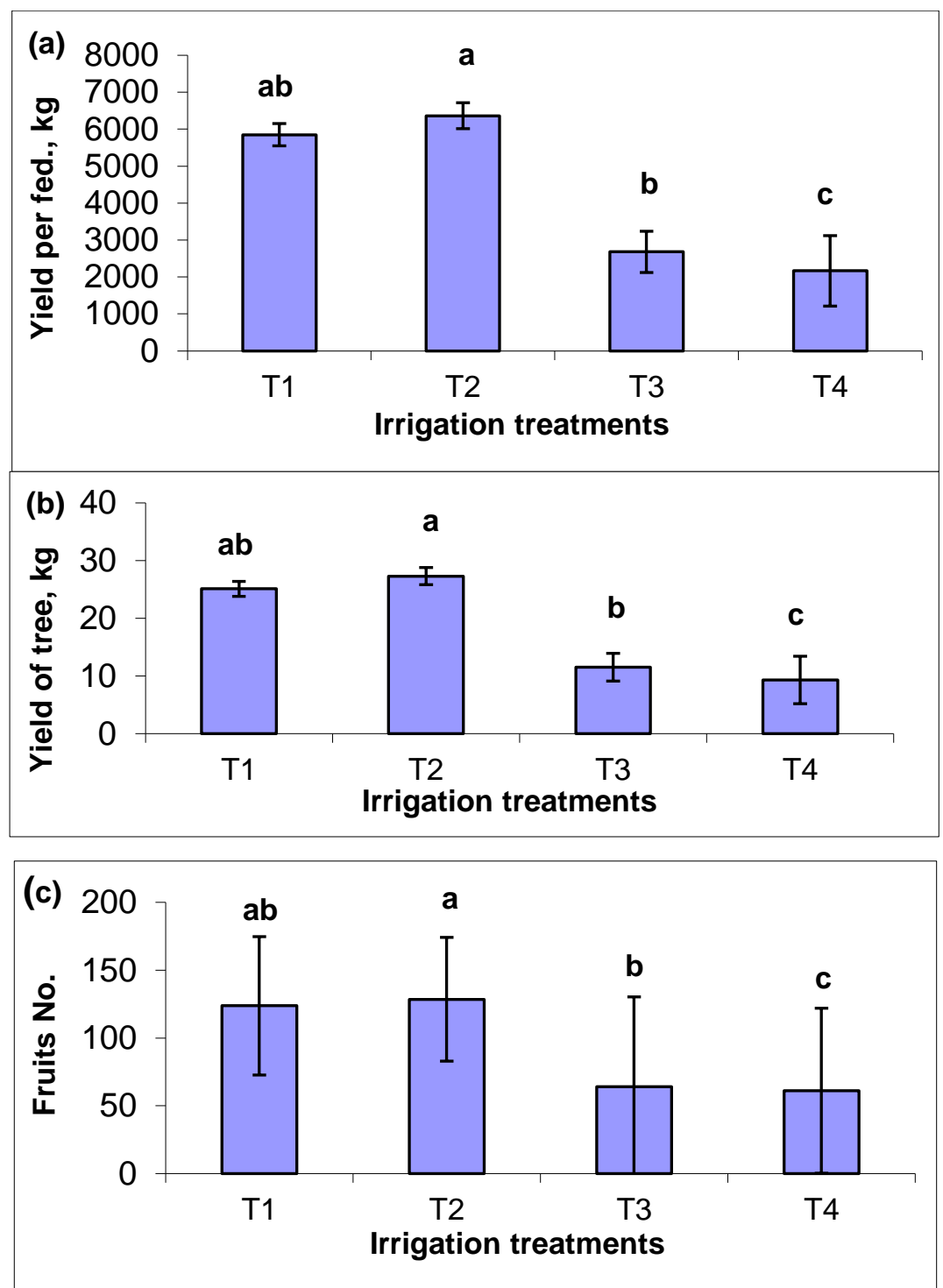

Fig. 6. The effect of water regimes on yield/ fed., yield of tree and fruits number.

Therefore, the T2 treatment reached the highest average yield per fed, yield per tree, and numbers of fruits per tree respectively being significant at (5\%) in comparison with the T3 and T4 treatments. Mango trees of T2 produced (1.1, 2.37 and 2.93) times more fruit yield than the T1, T3 and T4 treatments, respectively. By comparing the study years, the second 
year registered the highest fruit yield. This results were agreement with Spreer et al., (2009a).

The relationships of (a) yield, (b) volume, (c) total acidity and (d) leaf area vs. water requirements (water regimes) as shown in fig. 7 considering the average two growing seasons, were studied then the power relationships between yield $(\mathrm{kg} / \mathrm{fed})$, volume $\left(\mathrm{cm}^{3}\right)$, total acidity $(\%)$, leaf area $\left(\mathrm{cm}^{2}\right)$ and water requirements $\left(\mathrm{m}^{3} / \mathrm{fed}\right)$ found, an exponential model best fitted the data for productive parameters $\left(\mathrm{R}^{2}\right.$ equal to $0.72,0.81,0.86$ and 0.99 for yield, volume, total acidity, and leaf area, respectively. whose trend reveals how yield, volume and leaf area increases with increase water requirements. When, the total acidity increase with decrease water requirements. These results were agreement with Durán Zuazo et al. (2011).

The relation to the regression between (a) yield, (b) volume, (c) total acidity and (d) leaf area vs. water use efficiency (WUE) as shown in fig.8 considering the average two growing seasons, were studied then the power relationships between yield $(\mathrm{kg} / \mathrm{fed})$, volume $\left(\mathrm{cm}^{3}\right)$, total acidity $(\%)$, leaf area $\left(\mathrm{cm}^{2}\right)$ and WUE $\left(\mathrm{Kg} / \mathrm{m}^{3}\right)$ as shown in (fig.9) found, an exponential model best fitted the data for productive parameters $\left(\mathrm{R}^{2}\right.$ equal to $0.92,0.53,0.81$ and 0.37 for yield, volume, total acidity, and leaf area, respectively, taking into consideration the poor regression $\left(\mathrm{R}^{2}=0.53\right)$ between volume and water use efficiency. Whose trend reveals how yield, volume and leaf area increases with increase WUE. When, the total acidity increase with decrease WUE. Moreover, the average WUE during two growing seasons varied from 0.54 to $1.13 \mathrm{Kg} / \mathrm{m}^{3}$, maximum WUE was $1.13 \mathrm{Kg} / \mathrm{m}^{3}$ under (T2 irrigation level) and the minimum WUE was $0.54 \mathrm{Kg} / \mathrm{m}^{3}$ and $0.55 \mathrm{Kg} / \mathrm{m}^{3}$ under ( $\mathrm{T} 3$ and $\mathrm{T} 4$ irrigation levels). These results are due to lower production in the first season as a result of falling mango blossoms especially in (T3 and T4 irrigation levels). These results were agreement with (Dinesh et al., 2008) and Durán Zuazo et al., (2011). 

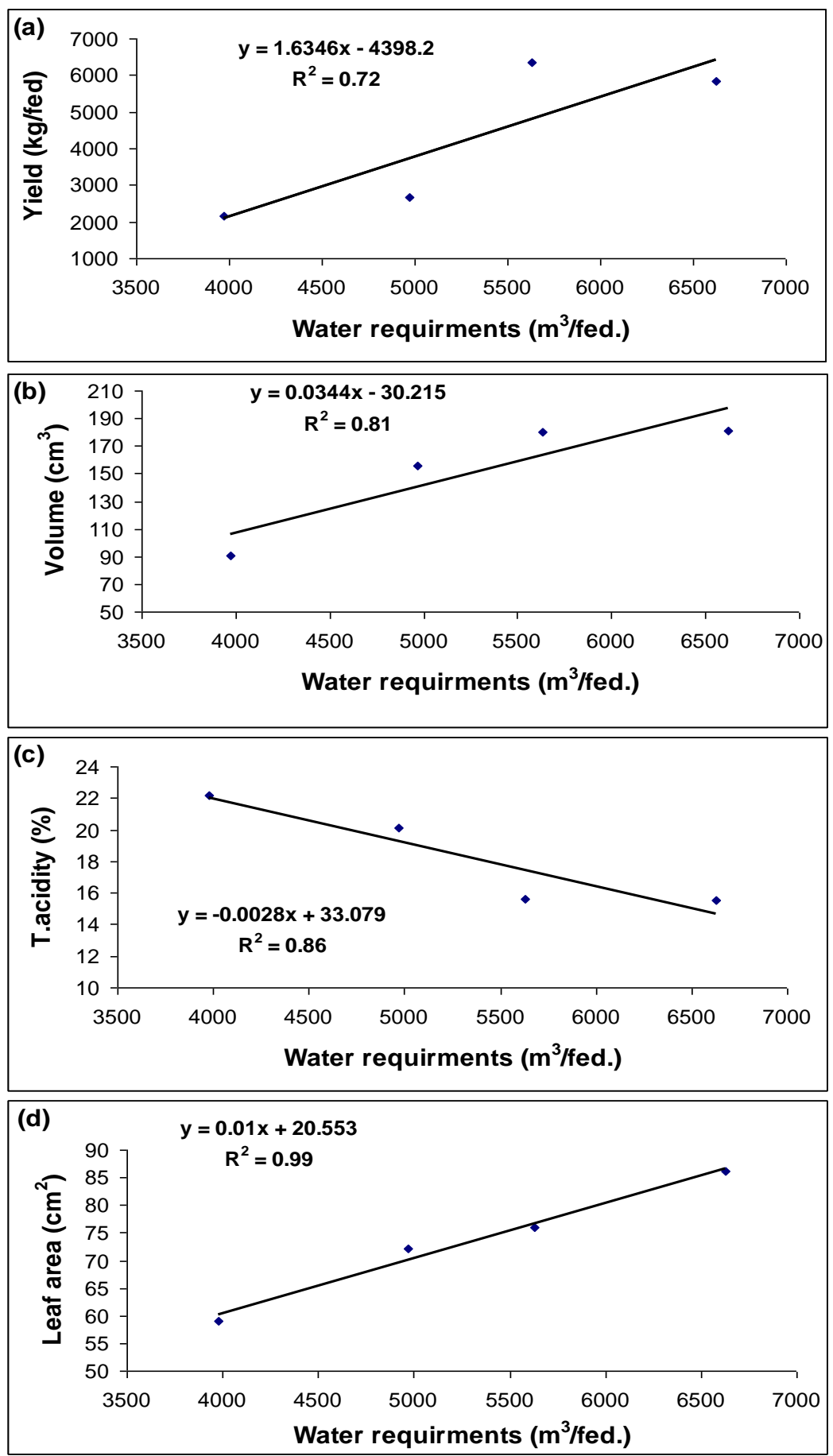

Fig. 7. The relationships between water requirements with yield, volume, total acidity and leaf area under four water regimes. 

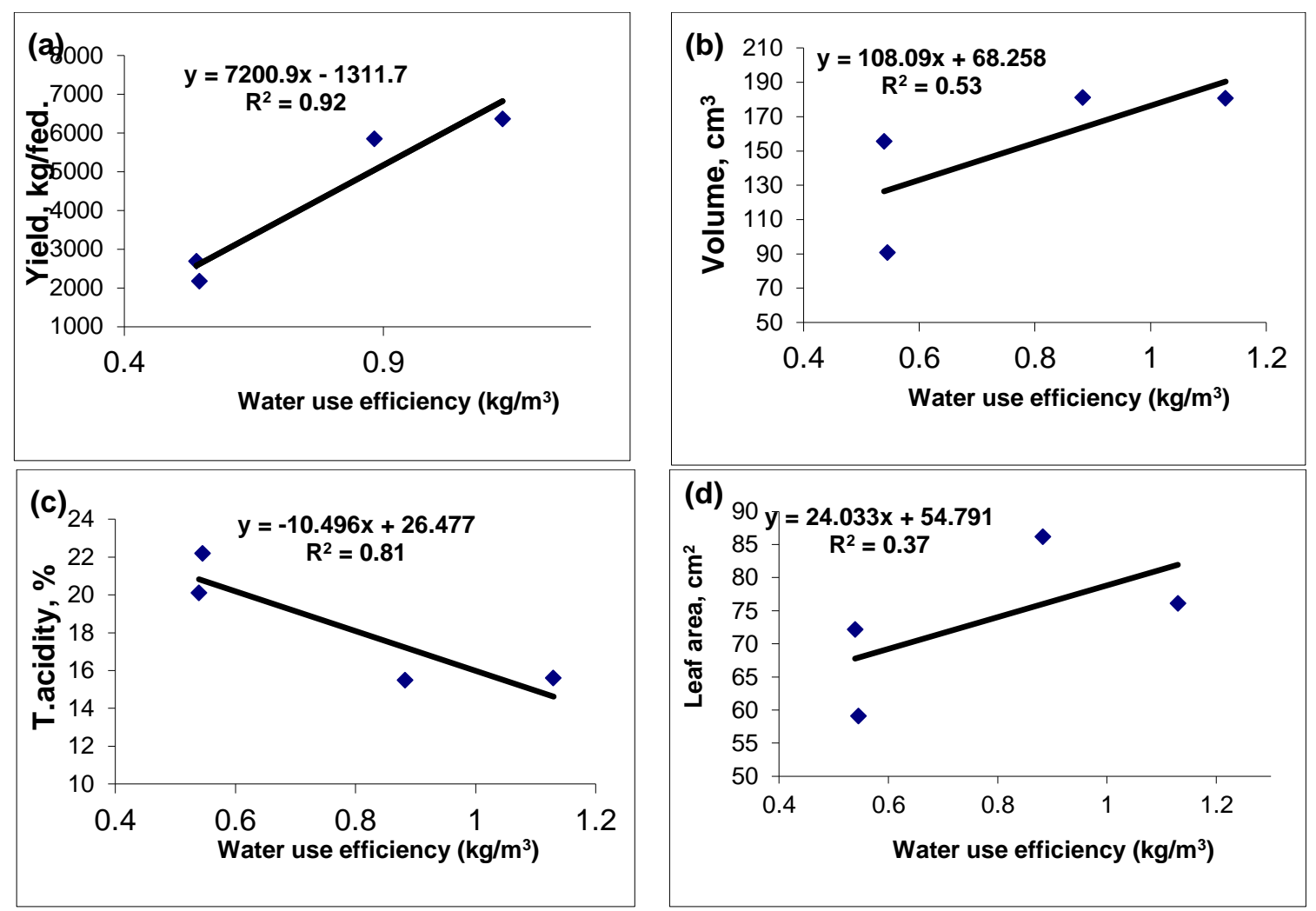

Fig. 8. The relationships between water use efficiency with yield, volume, total acidity and leaf area under four water regimes.

\section{CONCLUSIONS}

Our results demonstrated that the amount of irrigation in mango is important in order to improve the water-saving strategies for semi-arid sustainable agriculture in mango orchard. In the mango tree orchards studied, the highest yield and water-use efficiency were obtained with the T2 treatment (85\% moisture content of available water with farmyard manure with compost), and thus the greatest amounts of water did not result in the highest yield. In addition, water added requirements were strongly correlated with the yield, volume, total acidity and leaf area of mango orchard. Thus, according to the results of the present experiment, the sustained deficit-irrigation treatment with $85 \%$ of moisture content of available water should be adopted as the most appropriate irrigation strategy for achieving sustainable, efficient water management in mango orchards under a semi-arid climate. 


\section{REFERENCES}

Allen, R.G., L. S. Pereira, D. Raes, and M. Smith. (1998). Crop evapotranspiration. Guidelines for computing crop water requirements. FAO Irri. and Drain. Paper No. 56, FAO, Rome, Italy, 300 .

Ali, M.H., Hoque, M.R., Hassan, A.A., and Khair, A., (2007). Effects of deficit irrigation on yield, water productivity, and economic returns of wheat. Agr. Water Manage. 92, 151-161.

A.O.A.C., (1995). Association of official analytical chemists official and tentative methods of analysis The A.O.A.C., Washington D.C., USA.

Dinesh, K., Kumar, V. P., and Vishal., N. (2008) Effect of drip irrigation regimes on growth, yield and quality of mango hybrid Arka Anmol. Indian J. Hort. 65(4): 409-412.

Durán Zuazo V.H., Rodríguez P.C.R., and Tarifa (2011).Impact of sustained-deficit irrigation on tree growth, mineral nutrition, fruit yield and quality of mango in Spain. Fruits, 2011, vol. 66, p. 257268.

FAO Production Yearbook, (2007). Food and Agricultural Organization of United Nations. Rome.

Geerts, S., and Raes, D., (2009). Deficit irrigation as an on-farm strategy to maximize crop water productivity in dry areas. Agricultural Water Management 96 (9), 1275-1284.

Lovelli, S., M. Perniola, A. Ferrara, and T. Di Tommaso. (2007). Yield response factor to water (Ky) and water use efficiency of Carthamus tinctorius L. and Solanum melongena L. Agric. Water Manage. 92, 73-80.

MALR, (2013). Ministry of agriculture and land reclamation, Economic Affairs Sector: Study of important indicators of the agricultural statistics, 2012 and 2013, Cairo, Egypt. 
Mohamed, M.F., (2000). Useful tepary and cowpea lines in rationalising water use for pulse legume production in southern Egypt. Acta Hort., 537: 813-819.

Pavel, E.W. Villiers, A.J. de. (2004). Responses of mango trees to reduced irrigation regimes. Acta Horticulturae: (646): 63-68.

Silva, V. P. R.; Campos, J. H. B. C.; and Azevedo, P. V. (2009). Wateruse efficiency and evapotranspiration of mango orchard grown in northeastern region of Brazil. Scientia Horticulturae, v.120, n.4, p. $467-472$.

Spreer W, Müller J, Hegele M, Ongprasert S, (2009a). Effect of deficit irrigation on fruit growth and yield of mango (Mangifera indica, L.) in Northern Thailand. Acta Horticulturae 820, 357-364.

Spreer W., Ongprasert S., Hegele M., Wünsche J.N., Müller J., (2009b). Yield and fruit development in mango (Mangifera indica L. cv. Chok Anan) under different irrigation regimes, Agric. Water Manag. 96: 574-584.

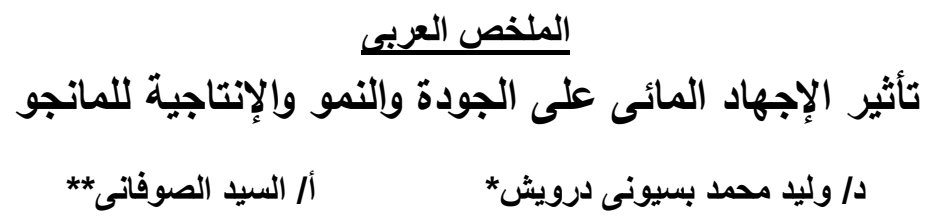

إن حالة نقص المياه فى المناطق الجافة وشبه الجافة يزداد سوءا بسبب التغير ات المناخية غير

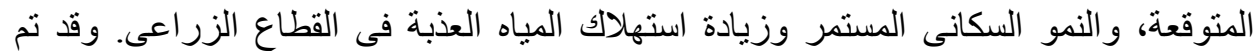

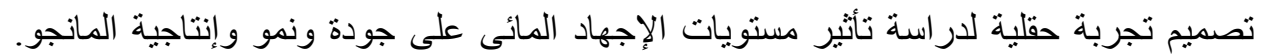
وكان الهذف من الدراسة هو تقييم أثر مستويات الإجهاد المائى على جلى جودة ونمو الأنى الأشجار

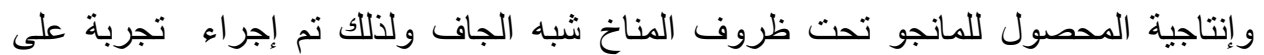

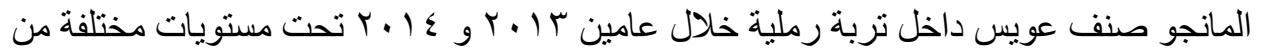

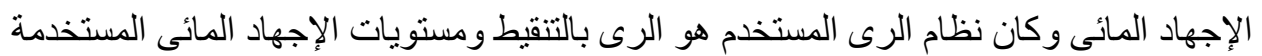

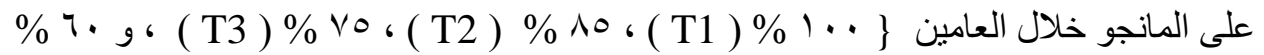

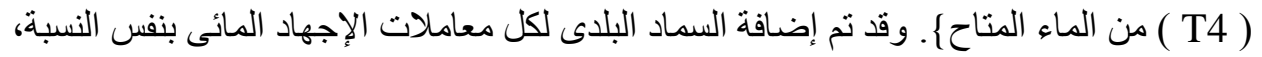

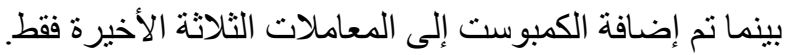




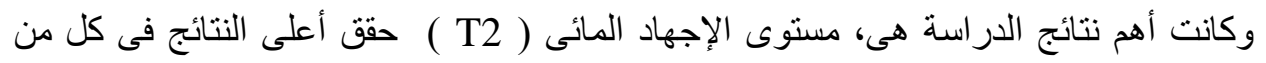

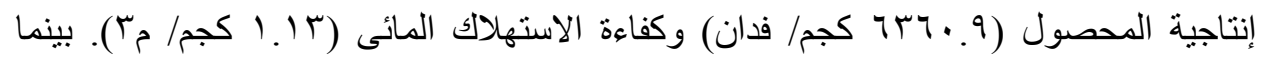

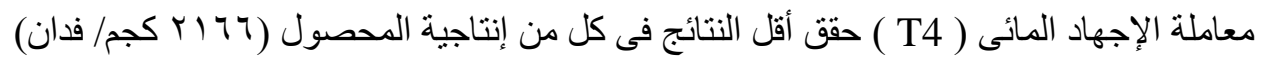

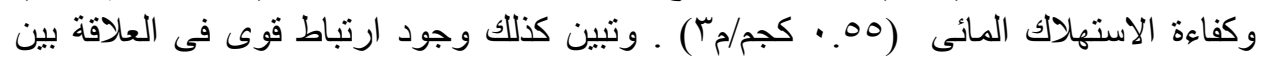

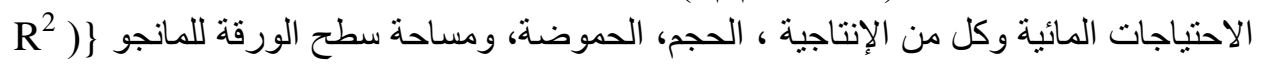

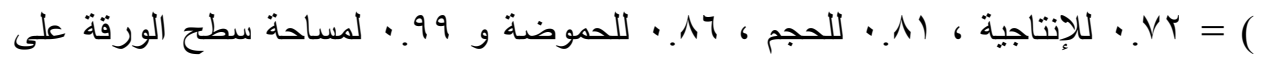

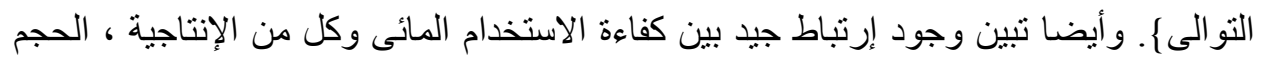

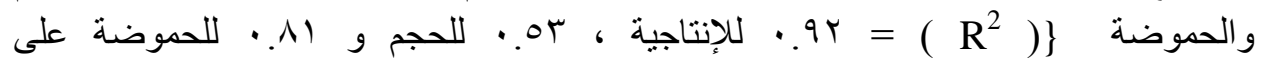

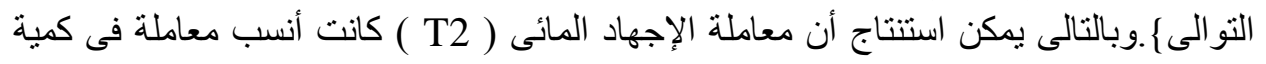

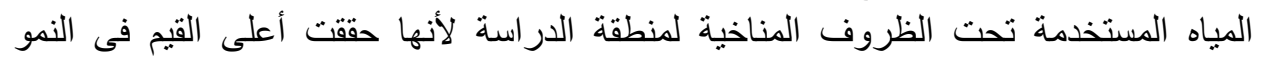

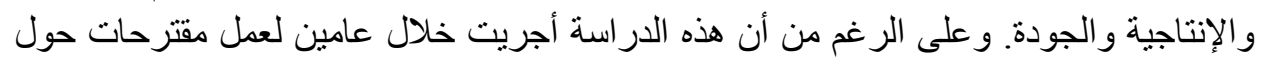

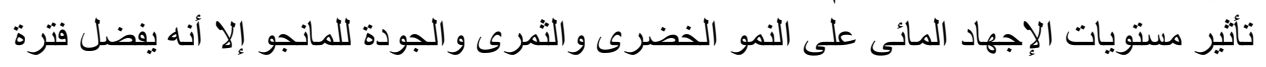

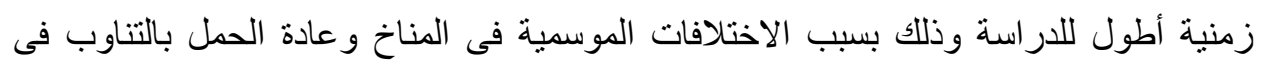

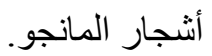

